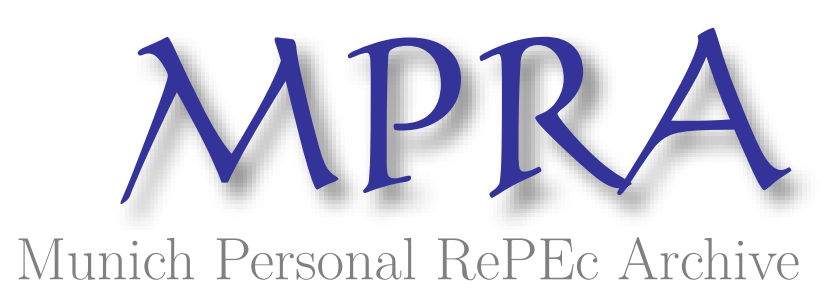

\title{
Third-Party Opportunism and the Theory of Public Contracts: Operationalization and Applications
}

Moszoro, Marian W. and Spiller, Pablo T.

SGH Warsaw School of Economics

2014

Online at https://mpra.ub.uni-muenchen.de/101592/

MPRA Paper No. 101592, posted 14 Jul 2020 13:06 UTC 


\title{
Third-Party Opportunism and the Theory of Public Contracts: Operationalization and Applications
}

\author{
Pablo T. Spiller \\ Haas School of Business, University of California, Berkeley, \\ New York University, \\ \& National Bureau of Economic Research \\ Haas F 593, Berkeley, CA 94720-1900, tel.+1-510-642-1502, spiller@haas.berkeley.edu
}

\author{
Marian W. Moszoro \\ IESE Business School, Barcelona \\ $\&$ Haas School of Business, University of California, Berkeley \\ Avd. Pearson 21, Barcelona 08043, Spain, +34-932-534-200, mmoszoro@iese.edu
}

\begin{abstract}
Public contracts seem to be "expensive" and "inefficient" compared to pure private contracts. Higher prices and inefficiencies in the implementation of public contracts result from their specificity and rigidity, which is how public agents limit hazards from third-party opportunism. We present a comprehensible and testable theory of third-party opportunism and its effects on public contracts. We show that, in the presence of third-party opportunism, there exists an equilibrium in which public contracts are specific and rigid, and thus more expensive in their design, implementation, and control than the theoretical first-best in a non-opportunistic world. We use case examples to extend the theory into practical settings and derive empirical implications.
\end{abstract}

Keywords: Transaction Costs, Procurement, Political Processes, Political Economy, Opportunism

JEL Classification: D23, D72, D73, D78, H57 
In contrast to private contracts, public contracts are open to challenge by third parties. The whiff of corruption and the concern for misuse of other people's monies ${ }^{1}$ make challenging public contracts feasible. High ex ante payment volatility or ex post flexibility in implementation may trigger implementation challenges, leading to contract failure or to costly adaptation by the public official, whether in terms of time or political career. Thus, even though the enactment and performance of a contract may be honest and legal, public agents may fear politically motivated challenges, and hence will ex ante adjust the nature of the contracts so as to limit those features whose probity may be questioned. These adjustments will imply more contract specificity in design and rigidity in implementation. Such contractual adaptation, however, is not costless. Contractors' perception of specificity and rigidity will translate into ex ante higher prices as well as on the enactment of stronger compensating clauses. The contractual complexity and adaptation required to limit the potential for third-party challenges, whether opportunistic or not, make public contracting look "inefficient" (Spiller 2008:16).

The higher level of contract specificity and rigidity in public contracting can be understood, then, as a political risk adaptation by public agents. ${ }^{2}$ It is not that civic-oriented legislation limits public agents' discretionary actions with "red tape," but rather that public agents limit the risk of third parties' challenges through contracting formalities and rigidities, externalizing the associated costs to the public at large.

This paper provides an operationalization of Spiller's (2008) third-party opportunism (TPO), towards an understanding of the organizational foundations of pricing, specificity, and rigidity - the outer features - of public contracts. Spiller's theory of public organization is rooted in a transaction costcum-positive political theory, where the nature of organizational adaptation of public contracts results from their inherent hazards. Spiller's framework follows Williamson's (2005) four cornerstones of

\footnotetext{
${ }^{1}$ What Williamson (1999:311) calls the hazard of probity posed by transactions organized in the public sector. ${ }^{2}$ As Goldsmith and Eggers (2004:122) underscore, "when something goes wrong in a public sector network, it tends to end up on the front page of the newspaper, instantly transforming a management issue into a political problem."
} 
the economics of governance-namely, governance, ${ }^{3}$ transaction $\operatorname{costs},{ }^{4}$ adaptation, ${ }^{5}$ and interdisciplinary social science ${ }^{6}$ - and introduces third-party opportunism as the quintessential hazard of public transactions.

\section{Prior Literature}

Third-party opportunism relates to a threefold literature on public contracting: industrial organization, public administration, and political economy.

In the industrial organization literature, public contract pricing is fundamentally determined by informational costs, arising from informational asymmetries, the extent of verifiability of information and the presence of repeated interactions (Bajari and Tadelis 2001; Laffont and Tirole 1993; Loeb and Surysekar 1994; Macaulay 1963; Marshall, Meurer, and Richard 1994a). Hart and Moore (2008) present a model with a trade-off between flexibility and rigidity in relational contracts, where the combination of ex ante competition and ex post lock-in makes the initial contract a useful reference point. In a flexible contract, a party may feel entitled to different outcomes within the contract and thus "shades by providing perfunctory rather than consummate performance" if she does not get what she expected (Fehr, Hart, and Zehnder 2011:494). It is, however, the nature of the hazards involved in public-private relations that determines the fundamental features of public procurement and contracting (Williamson 1979). Not only is "the nature of the agreement [...] carefully delimited, and the more formal features govern when [...] terms are contested" (Williamson 1979:236), but the potential for a contest from an excluded seller impacts the nature of the agreement (Marshall, Meurer, and Richard 1994a). Whereas private parties in private-private relations adapt to new information as it becomes available in order to save litigation cost (Williamson 1975), and courts are rather used to

\footnotetext{
${ }^{3}$ Williamson (2005:3) defines governance as "the means by which to infuse order, thereby to mitigate conflict and realize mutual gains."

${ }^{4}$ Acknowledging that hierarchies and procurement are "alternative methods of coordinating production" (Coase 1937:388).

${ }^{5}$ Not only though the price system, but also as a managerial decision.

${ }^{6}$ The need to incorporate insights from law, political science, and sociology to understand what the rough price theory cannot fully capture.
} 
termination disputes (Macaulay 1963:65-66), public contracts appear bureaucratic and overmonitoring in situations in which it is not needed (Prendergast 2003:932-933).

According to the public administration view, contracting inefficiencies are associated with the large number of formal processes that appear to be essential to ensure the public sector's functions as well as with "red tape," i.e., costly and compulsory rules, regulations and procedures with no efficacy for their functional object (Bozeman 1993:274). ${ }^{7}$ Bureaucrats are used only for "hard" agency problems, where consumers cannot be trusted (Prendergast 2003:933). Extensive rules and regulations arise from dividing authority among the separate branches of government (executive, legislative, and judicial), designed to prevent abuses of power, protect people's rights (Baldwin 1990:10-11), and reflect equity values not necessarily present in private firms, including educational, health-related, legal, and environmental (Forrer et al. 2010:480). Red tape regulations are intended to decrease public employees' uncertainty about how they should behave (Kurland and Egan 1999:440). Both formalities and red tape are the instruments by which bureaucracies restrict public agents' discretion (Boyne 2002; Lan and Rainey 1992) and "overcome the temptation to capitulate to consumers simply to avoid complaints" (Prendergast 2003:932).

The political economy profession has long been divided into advocates of public interest theory (in line with the public sector motivation literature), and "capture" or interest group theory of government intervention in industries, seeded by Buchanan (1965) and Olson (1965), and elaborated by Stigler (1971). This positive approach, both in its Chicago school (Becker 1983; Peltzman 1976; Stigler 1971) and Virginia school (Buchanan 1975; Buchanan, Tollison and Tullock 1980) modalities, concentrates on the demand-side, "black-boxing" the supply-side of political decision-making

\footnotetext{
${ }^{7}$ A report to Congressional Committees on a Congress-authorized test program to simplify the procedures for the acquisition of commercial supplies and services that allowed government buyers to eliminate certain procedural requirements when purchasing commercial items not exceeding $\$ 5$ million, i.e., allowing contract flexibility, indicated that although "data was not collected to provide a basis for measuring whether the test program produced the desired results of maximizing efficiency and economy and minimizing burden and administrative costs for both the government and industry, [...] the Office of Federal Procurement Policy survey of procurement executives in 1999 showed that these executives believed that the program has had a positive impact on the federal procurement process. [...] However, the survey did not collect empirical data that would have supported these views" (GAO 2001).
} 
(Laffont and Tirole 1993:475-476). On the other hand, positive political theory scholars, led by Riker (1963), focused on the supply-side of political decision-making, studying how politics-legislative procedures, administrative procedures, and bureaucratic oversight - affects legislative, judicial and regulatory behavior. ${ }^{8}$ Positive political scholars have also studied the use of interested parties (McCubbins and Schwartz 1984; de Figueiredo, Spiller, and Urbiztondo 1999) and consumers (Prendergast 2003) as instruments of oversight.

In addition to the mainstream political economy view of public contracting, there is an increasing literature on the crucial role of political motives in shaping public-private long-term relations. According to Hammami, Ruhashyankiko, and Yehoue (2006), private participation (from procurement to privatization) is positively correlated with less corruption and with an effective rule of law. Engel, Fisher, and Galetovic (2006) suggest that public agents, to increase their chances for reelection, prefer direct spending instead of more complex contracts subject to scrutiny. In developing countries, new administrations tend to renegotiate or unilaterally change concession agreements (Brench et al. 2005; Guasch, Laffont, and Straub 2007; Lobina and Hall 2003), i.e., reshape contract terms and appropriate rents. Iossa and Martimort (2008) conclude that long-term contracting can help to prevent cost overruns, but it requires institutions with strong commitment power and, as the risk of regulatory opportunism increases, the case for long-term contracting is weaker.

Laffont and Tirole (1993:9) emphasize that the link "between procurement and regulation and the associated administrative and political constraints is still unknown to us or is still in a state of conjecture. [...] Institutions are endogenous and should as much as possible be explained by primitive considerations." This paper is an attempt to operationalize the basic features of public contracting from its primitive considerations: its fundamental hazards.

\footnotetext{
${ }^{8}$ See, for example, Ferejohn (1990), Gely and Spiller (1990), McCubbins, Noll, and Weingast (1987, 1989), Weingast and Moran (1983).
} 


\section{A Heuristic Model of Third-Party Opportunism}

\subsection{Signaling process: hazards into rigidity}

We focus our analysis on the public agent's perspective. We ignore sunk costs to abstract from governmental opportunism, ${ }^{9}$ and to make the argument on TPO straightforward.

There are four agents explicitly and implicitly involved in public contracting:

a) Incumbent public agent

b) Private contractor

c) Third-party challengers, i.e., political opponents to the incumbent public agent, competitors to the contractor, and interest groups ${ }^{10}$

d) Public at large, i.e., voters and courts

The signaling process starts before the signing of a contract. The public agent is commissioned to use public monies and contract for goods and services. The public agent perceives the threat of potential third party challenges and tries to minimize political risks and maintain political support. Contract outcomes affect voters' opinions, thereby affecting electoral outcomes. If a public contract does not meet the expectations of the public, political consequences may include weakened chances of reelection for incumbent public agents (Forrer et al. 2010:480). The private contractor may not be directly aware of the hazards faced by the public agent, but observes contract specificity and rigidity. Specificity and rigidity equal less adaptability, higher contracting and implementation costs, and hence higher final prices charged to the public agent.

\footnotetext{
${ }^{9}$ See Spiller (2008) and references therein.

${ }^{10}$ In our understanding, the closest to a third-party challenger-reversing Buchanan's (1975:229) and Williamson's (1985:29) nomenclature - is an "anti-arbitrator," i.e., an outsider who tries to create conflict between parties who have reached an agreement. As an arbitrator lessens frictions and transaction costs, so a challenger to a public contract increases political costs to the public agent.
} 


\subsection{Conceptualizing contract specificity and rigidity}

Contract specificity refers to ex ante complexity of subject, completeness of clauses, technical provisions, and processing costs (Laffont and Tirole 1993:307). Contract rigidity refers to ex post enforcement, penalties, hardness, and intolerance to adaptation of contracts, ${ }^{11}$ and normally correlates with contract specificity: the more specific the contract is, the more rigid its implementation and enforcement is expected to be. Otherwise, if the contract is specific and then the parties agree to deviate, third parties can accuse the contracting parties of collusion.

Complex public contracts have more contractual rigidities than simpler contracts. The cost of ex post enforcement increases in complexity (Bajari and Tadelis 2001:393). Because the public sector has more ambiguous objectives than private organizations (Boyne 2002), and it is difficult to assess to what extent these objectives are achieved (Lan and Rainey 1992), public high specificity and rigidity mitigate ambiguity and problematic evaluation. For example, Department of Defense directives specify in great detail source selection policies, including the development of objective technical, cost, schedule, manufacturing, performance, and risk criteria, the auction techniques, the organization of the selection committee, and the pertinence of contacts with contractors. ${ }^{12}$ Public agents must also follow imposed standards of evidence, and may be constrained to formulate standards and follow their own rules to avoid discriminating between distinct situations on the basis of non-verifiable information (Laffont and Tirole 1993:5).

\subsection{Modeling hazards, rigidity, and pricing}

Third-party challenges may arise from honest attempts to control costs and from opportunistic attempts to replace the public agent. Third-party costs, then, have two components: third-party costs $T$ related to political costs of loss of office, reputation, and support that surge from contract

\footnotetext{
${ }^{11}$ In this regard, contract rigidity is the opposite of a "best efforts" clause.

${ }^{12}$ See the Department of Defense's memorandum on "Source Selection Procedures," issued on March 4, 2011, and effective July 1, 2011. Available at: http://www.acq.osd.mil/dpap/policy/policyvault/USA 007183-10DPAP.pdf (accessed May 19, 2011).
} 
discretionary terms (flexible contracting), and third-party costs $K$ that rise with expenses related to the contract. Part of these contracting costs is borne directly by the contractor $\left(K_{p r}\right)$ and reflected in the contract price, and part borne only by the public agent. If a third-party challenge is successful, there are also costs associated with the financial and social costs of a new tender, i.e., time and documentation, ${ }^{13}$ or settlement awards made by the winning bidders to protesters in exchange for a promise to drop their protest (Marshall, Meurer, and Richard 1994b). We underline political ${ }^{14}$ costs as the main cost for public agents concerning third-party challenges, and these costs are difficult to appraise, let alone to measure financially. The more discretionary the contact terms are, the more room there is for third parties to challenge the contract. Therefore, third-party costs $T$-both honest and opportunistic — can be mitigated by contract specificity and rigidity $R$.

Contract design (ex ante specificity), and implementation and enforcement (ex post rigidity) costs are subject to time needed for contract preparation, lawyers, documentation, and control, and can be measured financially. Contracting and enforcement costs $K$ rise with contract specificity and rigidity $R$. The public agent wants to keep $K$ low, because the more expensive a contract is, the more subject the public agent is to third-party challenges for misuse of funds.

In order to illustrate and operationalize the third-party opportunism theory of public contracts, we introduce some simple notation. Hazards faced by the public agent are subject to the likelihood of TPO challenge $\sigma$ and the likelihood of success of TPO challenge $\tau,{ }^{15}$ which are driven by contract complexity (sector-specific) and political contestability.

\footnotetext{
${ }^{13}$ Marshall, Meurer, and Richard (1994a) sustain that allowing excluded bidders to challenge the outcome of a procurement process inefficiently reduces sole-sourcing.

${ }^{14}$ Maser, Subbotin, and Thompson (2010) study the efficiency of the bid-protest mechanism in the US. In underlining "fairness" in contracting, i.e., that giving equal treatment to "all potential suppliers matters, not only to winners, but to losers as well" (Maser, Subbotin, and Thompson 2010:2; their emphasis), they characterize the challenger as a loser bidder and focus on the transaction-cost side of TPO, ignoring the political context of public agents. They make this point more explicitly next, recalling the rule-of-law doctrine: "official duties are supposed to be defined primarily by neither instrumental aims nor political pressure, but by law" (Maser, Subbotin, and Thompson 2010:3).

${ }^{15}$ We use the term "likelihood" instead of "probability" to underline that we refer here to singular public contacts, which have no statistical distribution of possible opportunistic behavior or third-party challenges. The likelihood of third-party challenge and the success of the challenge can be compounded, since what makes a challenge actual is its likelihood of success (likelihood of third-party challenge $\sigma$ increases in the likelihood of
} 
The price $P$ bid by the contractor is the sum of operating costs (company-specific), contracting costs for the private contractor (contract-specific subject to rigidity $R$ ) and a mark-up (economic profit). To simplify our argument, we assume a uniform technology across firms and a competitive bidding market, such that $P$ is the lowest possible cost and follows private contracting and enforcement costs $K_{p r}$. We also assume away governmental opportunism, i.e., government direct or incremental expropriation (Spiller and Savedoff 2000:9).

The likelihood of TPO challenge $\sigma$ is assumed to increase in complexity of transactions, as inherent public-private information asymmetries increase with complexity (Spiller 2008); "open accessibility" (North, Wallis, and Weingast 2006), as in open democracies there is more public participation, scrutiny, and accountability; proximity to elections, since political challengers arise as potential political gains increase; and decrease in cost of challenge (costs of court litigation, new elections campaign) relative to the gains and value of a contract, and rigidity $R$, as there is less room for challenge.

Given that it is harder to prove wrongdoing when there is less room for discretionary actions, the likelihood of success of TPO challenge $\tau$ is also assumed to decrease in rigidity $R$, as the courts are more likely to dismiss and the public to ignore challenges to more specific and rigid-"narrower"contracts. As both $\sigma$ and $\tau$ decrease in $R, \mathrm{E}(T)$ costs fall as well in $R$. The simple intuition that $\mathrm{E}(T)$ costs fall in $R$ is that the likelihood of a successful TPO challenge can be reduced to negligible by extreme contract rigidity—all deviations are observed and hence directly prosecuted.

$\mathrm{E}(T)$ costs are decreasing in $R$, while $K$ costs - both public and private-are increasing in $R$. The optimal level of rigidity $R^{*}$ is, therefore, driven by TPO costs, actual contracting and enforcement costs, and beliefs of the public agent about $\sigma$ and $\tau$.

success of the challenge $\tau$ ). Every challenge has some probability of success; otherwise the challenger would lose resources and reputation. 


\section{Figure 1 Third-party opportunism costs, and contracting and enforcement costs}

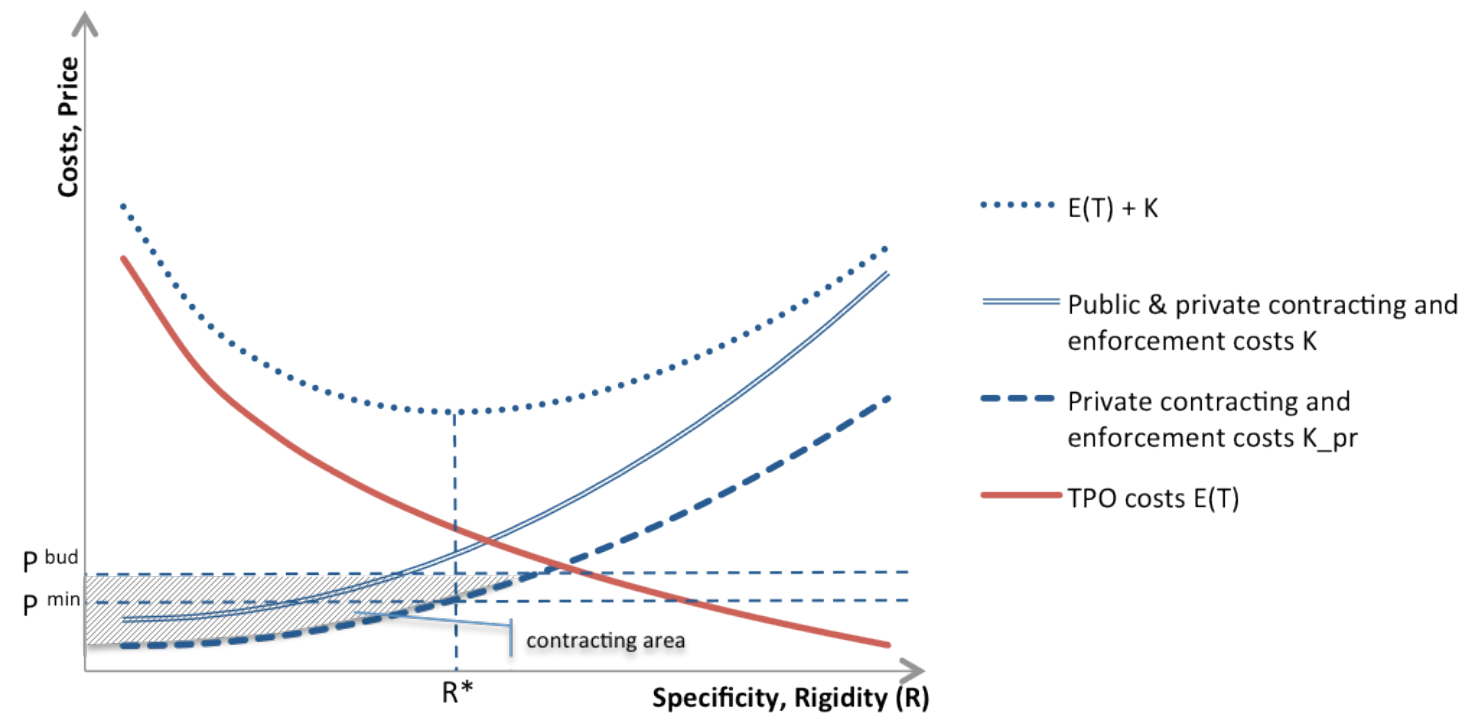

The position of the $\mathrm{E}(T)$ curve depends primarily on the political costs of a successful challenge to the incumbent public agent, and also on the costs of a new tender (documentation, new analyses), cost of externalities (including the value of lost time for users),${ }^{16}$ and the public agent's reputation. The slope of $\mathrm{E}(T)$ is a function of the likelihood of a successful TPO challenge. As both $\sigma$ and $\tau$ are decreasing in $R, \mathrm{E}(T)$ is decreasing and strictly convex in $R$.

The position of the $K$ curve is a function of materials and labor costs to be incurred, and also cost of time to close a contract, professionals needed (lawyers, engineers, consultants), required documentation, and control. The slope of the $K$ curve is a function of the marginal cost of contracting and enforcement—what Laffont and Tirole (1993:307) call "processing costs." By assuming them to be non-decreasing in contract specificity and rigidity, $K$ is rising and convex in $R$.

\footnotetext{
${ }^{16}$ E.g., highway repair generates significant negative externalities for commuters through increased gridlock and commuting times. Bajari and Lewis (2010:2) take the example of Interstate 35W, a main commuting route in Minneapolis carrying over 175,000 commuters per day. If a highway construction project results in a 30-minute delay each way for commuters on this route, the daily social cost imposed by the construction would be 175,000 hours. If we value time at $\$ 10$ an hour, this is a social cost of $\$ 1.75$ million per day. Most public contracts affecting the public at large, from sewage disposal to worse service because of a delay in buying IT equipment, carry externalities.
} 
We assume that the public agent fully internalizes expenses related to the contract, i.e., at the end, she is politically accountable, directly or indirectly, for all costs borne. ${ }^{17}$ She has to pay contractors' costs and her own costs, and she has also to minimize political costs. The sum curve of the expected thirdparty opportunism costs $\mathrm{E}(T)$ plus contracting and enforcement costs $K$ is U-shaped. It implies that the optimal contract is non-flexible and of finite rigidity. A too-flexible contract would be politically too risky while an over-rigid contract would be too expensive. The corollary is that, in the presence of third-party opportunism, the optimal public contract that minimizes political and contracting costs is specific and rigid, ergo more expensive in its design, implementation, and control than the theoretical first-best price in a non-opportunistic world. ${ }^{18}$ A direct outcome is that the higher the expected political costs of challenge, ceteris paribus, ${ }^{19}$ the higher the optimum contract rigidity and price will be.

\section{Contract Price Under TPO}

In every tender under budgetary constraints, the public agent sets-explicitly in tender information, announcements or the budget, or implicitly in internal regulations - a maximum price $P^{\text {bud }}$ that she can pay the contractor. To lessen TPO, she also adjusts contract specificity and rigidity at $R^{*}$. The acceptable contracting price-rigidity sets for the public agent are below the maximum contract price $P^{b u d}$, i.e., contracts "in the budget," subject to low TPO costs. The contractor sees specificity and rigidity $R^{*}$ in the tender documentation and bids accordingly. On the contractor's side, the acceptable price-rigidity sets are those on and above her private contracting costs $K_{p r}$. Therefore, the contracting area-i.e., the sets acceptable to both the public agent and the contractor-is given by price-rigidity combinations above $K_{p r}$ and below $P^{\text {bud }}$. At a given $R^{*}$, the minimum price required by the contractor

\footnotetext{
${ }^{17}$ Our main argument also holds for partial internalization by the public agent of expenses related to the contract.

${ }^{18}$ Thus, TPO does not lead to a "vicious cycle" as suggested by Maser, Subbotin, and Thompson (2010:4). In a game theory set, this state can be described as a Bayesian Nash equilibrium.

${ }^{19}$ A certain degree of specificity and rigidity is inherent to every contract, even in the absence of TPO, to avoid the standard contractual opportunism by the contractor (e.g., shading on quality) and the public agent (e.g., delay in payments, haggling). For simplicity, and to underscore TPO, we abstract from relational opportunism. The degree of specificity and rigidity $R$ presented in Figure 1 and 2 are beyond the levels of specificity and rigidity inherent to relational contracts.
} 
is $\mathrm{P}^{\text {min }}$. Figure 1 plots $\mathrm{E}(T)$ and $K$ curves, bid and budgeted and minimum prices, optimal rigidity, and the price-rigidity contracting area.

Before the tender, especially in complex contracts and given the contracting rigidities, the public agent only has an estimation of the contractor's costs $K_{p r}$, but does not know them with certainty. If $P^{\text {bud }}$ budgeted by the public agent is below the minimum acceptable price $P^{\text {min }}=K_{p r}$ for the contractor at a given $R^{*}$, then there will be no bidders at that level of $R$, or-in the case that $P^{b u d}$ is not known by bidders prior to the tender-bidders will bid $P>P^{\text {bud }}$ and the tender will be annulled. Therefore, "no contract" is a possible outcome if political risks are significant and budgeted expenses are too low at a given rigidity. ${ }^{20}$ In this case, the tender will have to be redesigned at a lower rigidity level at the risk of higher TPO for the public agent; the budget reconsidered, creating room for thirdparty challenges attempting to control budget expenses; or terms negotiated after bidding, increasing TPO on suspicion of collusion.

\section{Applications and Empirical Implications}

The base case that our model tackles is a simple public procurement contract. However, there are other situations where TPO can explain the mechanisms related to public procurement and efficiency. We now apply and extend the framework to practical settings to derive empirical implications.

\subsection{Bureaucracies}

Civil servants are subject to more specific and rigid contracts (e.g., regulated hiring, list of duties and responsibilities) than their peers in the private sector. ${ }^{21}$ A private company can hire whoever it wants and a typical employment contract may simply say "follow the instructions of your principal," while in a public institution the process of employment of civil servants is highly formalized and procedural,

\footnotetext{
${ }^{20}$ Scarce budgeted expenses for transport infrastructure along with excessive contract specificity and rigidity due to continuous TPO can explain the paralysis in highway development in Poland during the last decade. See "Poles repositioned," Project Finance Magazine, October 23, 2010.

${ }^{21}$ In this instance, bureaucrats as individuals are the private party contracting with the public agency.
} 
and responsibilities are detailed in civil service laws and internal regulations of the agency, department, office, and section in question (Horn 1995:20, 88, 112), and subject to independent ordinary and extraordinary controls (Horn 1995:98). ${ }^{22}$ Both specific employment procedures and rigid contracts in the civil service are aimed at avoiding challenges of favoritism (Horn 1995: 101; GAO 2003), but nonetheless result in civil servants being allowed less discretion, less initiative in bringing solutions, and lower productivity ${ }^{23}$ (analogical to higher price in public tenders). TPO thus provides a consistent explanation of civil service inefficiencies broader than the public administration view on red tape. ${ }^{24}$

Bambaci, Spiller, and Tommasi (2007) describe the Argentine bureaucracy as a combination of constitutional protections of civil servants, relative low wages, ${ }^{25}$ and low accountability to "short lived" political public agents, ${ }^{26}$ which produces unresponsive bureaucrats with few incentives to invest in their own capabilities. Precisely because political public agents do not last long, TPO is not a prevalent hazard for them. The institutional adaptation that emerged is the large use of a "parallel bureaucracy,"27 i.e., temporary contracted professionals, better paid, more responsive to their principals, under a more flexible regime than permanent bureaucrats, and whose appointments are left to the discretion of the principal public agent in office (Iacoviello and Tommasi 2002; Bambaci, Spiller, and Tommasi 2007:172-174). Thus, political public agents in Argentina blend permanent bureaucracy with temporary bureaucrats who respond more flexibly and efficiently.

\footnotetext{
${ }^{22}$ For example, controls may be overseen by the Government Accountability Office in the USA, the Australian National Audit Office in Australia, the Tribunal de Contas da União in Brasil or the Bundesrechnungshof in Germany, to name a few.

${ }^{23}$ According to the British Office for National Statistics (ONS), public sector productivity fell by $3.4 \%$ in 1997 2006 , compared with a rise of $28 \%$ in the private sector over the same 10 -year period (see Robert Watts, "Public sector pay races ahead in recession," The Sunday Times, January 3, 2010).

${ }^{24}$ See Bozeman (1993). See also Laffont and Tirole (1991), Pfiffner (1987), and Spiller and Urbiztondo (1994).

${ }^{25}$ In 1999, Federal Government wages divided by GDP per capita equaled 1.65 in Argentina, compared with 3.70 in Brazil, 3.25 in Colombia, 3.05 in Chile, and 1.99 in Mexico. See Carlson and Payne (2003).

${ }^{26}$ The low accountability of the Argentinian administration is in large extent due to the high turnover of political public principals: ministers, secretaries, and undersecretaries of state. For instance, the average tenure of Ministers of Finance in 1950-1989 was 1 year, compared with 2.4 years in developed countries and 2.0 in developing countries (Bambaci, Spiller, and Tommasi 2007:165).

${ }^{27}$ In 1998-1999, parallel bureaucrats accounted for 17\% in the Presidency office, but 63-88\% in ministries (see "Estudio exploratorio sobre la transparencia en la Administración Pública Argentina: 1998-1999," Oficina Anticorrupción, Ministerio de Justicia, 2000, cited in Bambaci, Spiller, and Tommasi 2007:172).
} 


\subsection{Fixed-Price vs. Cost-Plus Contracts}

In theory, fixed-price contracts are preferable when the adverse selection problem decreases relative to the moral hazard problem (e.g., in the procurement of standardized goods and services, or in projects involving a low level of informational asymmetry between the contracting parties), while cost-plus procurement is preferable when the adverse selection problem increases relative to the moral hazard problem (i.e., when uncertainties related to technological requirements are unknown and bigger than the inefficiencies arising from incomplete monitoring and insulation of the contractor from cost overruns) (Loeb and Surysekar 1994).

In practice, cost-plus contracts have been criticized by the administration, lawmakers, and taxpayers for frequent and substantial cost overruns in government contracting. A GAO (2008) study of 95 major defense acquisition projects found cost overruns of 26 percent, totaling $\$ 295$ billion over the life of the projects. Cost-plus contracts are more flexible to adaptation, but also subject to potential abuse $^{28}$ and shading (Fehr, Hart, and Zehnder 2011). The Presidential Memorandum of March 4, 2009, for the Heads of Executive Departments and Agencies on Government Contracting, explicitly stated that "there shall be a preference for fixed-price type contracts. Cost-reimbursement contracts shall be used only when circumstances do not allow the agency to define its requirements sufficiently to allow for a fixed-price type contract. ${ }^{" 29}$ In the presence of closer third-party oversight and fear of $\mathrm{TPO},{ }^{30}$ public agents will prefer fixed-price contracts in settings where cost-plus contracts could prove to be more efficient. ${ }^{31}$

28 Cost-plus contracts are seen as a "blank check" for contractors and the root cause of procurement inefficiencies. A notable exception is the case of London's Heathrow Airport Terminal 5, which was delivered on schedule and under budget, under a cost-plus regime (see http://www.airport-technology.com/ projects/heathrow5/; accessed July 10, 2011).

${ }^{29}$ See Presidential Memorandum of March 4, 2009, for the Heads of Executive Departments and Agencies on Government Contracting, retrieved from http://www.whitehouse.gov/the press_office/Memorandum-for-theHeads-of-Executive-Departments-and-Agencies-Subject-Government/ (accessed July 11, 2011).

${ }^{30}$ As stated in the Presidential Memorandum (op. cit.), "reports by agency Inspectors General, the Government Accountability Office (GAO), and other independent reviewing bodies have shown that noncompetitive and cost-reimbursement contracts have been misused, resulting in wasted taxpayer resources, poor contractor performance, and inadequate accountability for results" and "improved contract oversight could reduce such sums significantly" (emphasis added).

31 Analyzing major defense acquisition programs, Wang and San Miguel (2011) argued that fixed-price contracts do not provide adaptable risk-sharing mechanisms and may lead to an unintended increase in 


\subsection{Public-Private Partnerships and Key Performance Indicators}

A public-private partnership (PPP) is a public service business operated under a long-term contract or license associated with a degree of exclusivity within a certain geographical area. It may involve the transfer to the private contractor of the right to use some existing infrastructure required to carry out a business (such as a water supply system in a city) and commonly the private contractor assumes substantial financial, technical, and operational risk in the project.

PPPs allow for ex ante flexibility in contracting to gain efficiency. To control quality ex post, Key Performance Indicators (KPIs) are used, i.e., measures specifically tailored for each sector, under which the private partner is evaluated. At the same time, KPIs constitute a signal for the public at large (consumers and voters) that the service, although privately provided, remains publicly accountable. KPIs are thus crucial to third-parties' perception of PPPs.

Ex ante flexibility, however, makes PPPs vulnerable to third-party challenges (higher $\sigma$ ), a hazard that private investors translate into higher prices. A number of Australian studies of private investment in infrastructure (Economic Planning Advisory Commission 1995; Harris 1996; House of Representatives' Standing Committee on Communications Transport and Microeconomic Reform 1997; Industry Commission 1996; Quiggin 1996) reached the conclusion that, in most cases, the PPPs were inferior - overall more expensive for the public or delivered lower quality of services - than the standard model of public procurement based on competitively tendered construction of publicly owned assets. One response by public agents to these negative findings was the development of formal procedures for ex ante assessment of PPPs using the Public Sector Comparator (PSC) and Value-for-Money (VfM) methodologies, i.e., introducing more contractual ex ante specificity and contractual costs. ${ }^{32}$

government payments. See also Tony Purton, "The case for a return to 'cost plus'," Defense Viewpoints, March 24, 2007, http://www.defenceviewpoints.co.uk/articles-and-analysis/the-case-for-a-return-to-cost-plus (accessed July 10, 2011).

32 See, for example, Department of Treasury and Finance of Victoria, "Partnerships Victoria Guidance Material: Public Sector Comparator - Technical Note," Melbourne 2001. 
In 2009, the Treasury of New Zealand, in response to inquiries by the new National Party government, released a report on PPPs that came to the conclusion that "there is little reliable empirical evidence about the costs and benefits of PPPs" and that "the advantages of PPPs must be weighed against the contractual complexities and rigidities they entail." 33

In the presence of TPO, public agents would pursue private provision of public goods mostly in projects where-assuming internalization of contract expenses by the public agent-expected political benefits gains from lower contract specification and better private management offset increased ex ante contracting costs related to compliancy with cost-benefit assessment and higher ex post rigidity related to KPIs.

\subsection{Public-to-Public Contracts}

When a public agent engages in a contract with another public agent (e.g., a state contracting a service from a government-owned enterprise) or a quasi-public agent (e.g., a state negotiating salaries with a public-employee union) ${ }^{34}$, both sides have to respond to their constituencies (i.e., the public agent to voters; the union leader to union members). TPO costs rise because of double scrutiny and higher likelihood of political challenge on both sides. Higher expected TPO costs result in higher contract rigidity. If the public agent subsidizes the government-owned company, higher contract rigidity might not be directly reflected in higher prices, but indirectly, e.g., through taxes or lower delivered quality of services. Public agents and government-owned companies or public-employee unions can agree to

\footnotetext{
${ }^{33}$ Brian Rudman, "Promised electric trains derailed by misguided enthusiasm." The New Zealand Herald. June 1, 2009. Emphasis added.

${ }^{34}$ See The Becker-Posner Blog entry for March 27, 2011: "Public-Employee Unions" by Richard Posner and "Government Sector Unions" by Gary Becker (http://www.becker-posner-blog.com/, accessed March 28, 2011). As Becker notes, "even without the strike threat—indeed, possibly even without unions - public employees can often extract considerable benefits from local, state, and the federal government in the form of higher earnings and generous pensions and health benefits. Public employees form a sizable voting bloc with formidable resources of money and the time of members to spend on supporting political candidates who they expect will be generous when it comes time to bargain over compensation."
} 
low contract specificity and rigidity only if there is strong political leadership and low political contestability (low TPO costs), as in authoritarian regimes. ${ }^{35}$

\subsection{External Consultants and Certification of Contractors}

The engagement of independent consultants (e.g., multilateral agencies, international advisers, especially in countries with weak law systems) strengthens the objectivity of procurement processes and prevents third-party challenges that cooperation between public agents and private contractors has crossed the line and become collusion.

Moszoro and Krzyzanowska (2008) report the use of external consultants in the city of Warsaw in the pre-procurement planning phase when it wanted to introduce novel PPP contracts: firstly, to overcome the lack of expertise in complex contracting (to reduce $K$ ) and, secondly and most importantly, to "safeguard the city authorities against complaints and criticism by subsequent administrations." While the city authorities could have designed the tender process in-house, they seem to have outsourced it to reduce TPO. The use of external consultants, however, came at a cost: PLN 10 million $(\$ 3.2$ million), i.e., $1.2 \%$ of the estimated budget for those projects.

Similarly, certain public tenders require certification of contractors and sub-contractors (Bajari and Lewis 2010), increasing contract specificity and the price of the tender. In May 2010, a public procurement for the "Canal Safety and Drainage Improvements Project" in Antioch, Pittsburg, Bay Point, Clyde and Walnut Creek (California), tendered by the Contra Costa Water District Construction Department, was objected to by JMB Construction. ${ }^{36}$ JMB Construction argued that the apparent low bidder Con-Quest Contractors included a non-certified subcontractor. According to Contra Costa Water District Construction Department, the relevance of the works the alleged subcontract would provide was minimal for the project overall; however, the challenger argued that the inclusion of a non-certified subcontractor allowed Con-Quest Contractors to bid a lower price

\footnotetext{
${ }^{35}$ See discussion in Section 4.6 below.

${ }^{36}$ See: http://www.ccwater.com/buscenter/109067_results.pdf (accessed May 28, 2010).
} 
(\$756,000 compared with JMB Construction's $\$ 852,000$, i.e., $11 \%$ cheaper) than if it had included only certified subcontractors. ${ }^{37}$

In both cases - the use of external consultants and certification of contractors - the implicit aim is to lessen the likelihood of TPO challenge $(\sigma)$. There is a trade-off for the public agent between lower TPO hazards and additional contracting costs $K$ of external consultants and certification. The public agent will employ external consultants and certification when additional contracting costs $K$ incurred are lower than price gains in contract flexibility due to lower $\mathrm{E}(T)$ and $R^{*}$.

\subsection{Efficient Small Communities and Authoritarian Regimes}

Small local governments (towns, counties) can be more efficient in public contracting than larger governments (metropolises, states). Due to lower value of contracts in comparison to larger governments, the benefits from political challenge are relatively low. Thus the likelihood of challenge is lower and subsequently potential TPO costs are lower. The public agent can therefore engage in more discretionary contracts and incur lower transaction costs.

Coviello and Gagliarducci (2010) present a study covering 3,825 Italian municipalities and 27,537 auctions, where an increase in the mayor's tenure of one term is associated with fewer bidders per auction $(-23.28 \%)$, higher probability that the winner is local $(+3.20 \%)$ and that the same firm is awarded repeated auctions $(+25.52 \%)$, i.e., more discretionary contracting $\left(\right.$ lower $\left.R^{*}\right)$ correlated with longer tenure. They also find evidence that a high level of heterogeneity within the government coalition reduces the possibility of favoritism in shaping the procurement process, that less "colluded" 38 mayors are more likely to gain reelection and survive longer, and that citizens and competitors are more likely to closely monitor large public projects.

\footnotetext{
${ }^{37}$ Based on an interview held in May 2010 with a Contra Costa Water District engineer.

${ }^{38}$ Coviello and Gagliarducci (2010) argue that mayors' time in office progressively lead to a long-term relation ("collusion") with a few favored bidders, and propose two interpretations: one based on favoritism and bribes in procurement, and another based on a learning process of mayors about the quality of contractors and a preference for highest-quality contractors with work (2010:26-27).
} 
Two reasons can be given why mayors with longer tenure show low concern about TPO and contract discretionarily. First, the Italian electoral system in municipalities is a simple majority regime. Consequently, in very small municipalities, more political contestability results in more dispersed voting and relative advantage of incumbent mayors. ${ }^{39}$ Second, procurement protests in Italy go through courts, where penalties for breaking procurement laws are hardly enforced. ${ }^{40}$ When $K$ increases more rapidly than $\mathrm{E}(T)$ decreases in $R$ or $\mathrm{E}(T)$ are insignificant due to lack of political contestability (as seems to be the case in Italian municipalities), the outcome is discretionary procurement. $^{41}$

Authoritarian regimes, where the likelihood of challenging the incumbent public agent is low, can contract public works more discretionarily and, thus, cheaper and quicker. The lack of opportunities for TPO can help to explain the rapid contracting and development of infrastructure in Paraguay during the Stroessner regime. Molinas et al. (2006:12-13) report the significant ability of the regime "to reap the benefits offered by long-term economic opportunities. (...) [Development programs were] possible because of the intertemporal 'cooperation' of the key actors (the government, the Party and the Armed Forces). The adaptation of the development model to allow for increasing integration with Brazil would have been unlikely under short-lived governments like the ones characterizing the postChaco war period (1936-1954). During that 18-year period, there were 12 different presidents, and political volatility prevented an adaptation to changing economic environments. (...) During the 1960s and the 1970s, Paraguay built roads, silos and, most importantly, the biggest dam in the world, the Itaipú Hydro-electric Dam, built jointly with Brazil. The long-term growth strategy turned out to be

\footnotetext{
${ }^{39}$ If $m$ is the population and $n$ the number of candidates, a candidate needs $m / n+1$ votes to win the election.

40 During the period 2005-2008, the Italian central purchasing authority CONSIP made 4,095 random inspections on the ex post renegotiations of procurement contracts for goods and services, and found a total of 1,455 contractual infringements. Only $4 \%$ of the associated penalties were paid (Coviello and Gagliarducci 2010:27). Anecdotally, it takes on average more than 10 years for juries to come to a verdict on contract protests. How public contracting can actually take place in an environment in which penalties are seldom paid remains a subject of future research.

${ }^{41}$ Coviello and Gagliarducci (2010) also report-contrary to our predictions - an increase in contract prices (reduction of winning rebate by $-12.68 \%$ ) along with an increase in contract discretion. According to those authors, higher prices are not due to higher cost of procurement and contract terms (the study analyzed the procurement of standardized items), but are driven by mayors' favoritism and colluded renegotiations (corruption) or preference for higher-quality contractors.
} 
effective. During the 1960s, real GDP growth was 4.2 percent. During the 1970s, Paraguay had one of the highest growth rates in the region, with real GDP increasing at 8 percent over the decade." That ability to move policy decisively and effectively by an authoritarian regime, however, also funneled most of the benefits from this fast development period to a few contractors and subcontractorscompanies owned by the dictator's followers (Fogel 1993:16).

\subsection{Privatizations of Government-Owned Companies}

Privatizations of government-owned companies ${ }^{42}$ are usually subject to clauses of commitment of the private acquirer over labor retention, modernization processes, future investments and other social sensitive issues. On the one hand, rigid privatization contracts (high $R^{*}$ ) take place in the fear of TPO challenges to the incumbent public agent by labor unions, the local community, and the political opposition. In order to minimize TPO challenges to privatizations, public agents embed in privatization contracts clauses and golden shares that allow them to limit "cream skimming" (Kolderie 1986) and the discretion of the private investor. On the other hand, such privatization clauses limit the governance of the company and, consequently, lower its value (analogical to a high price in a public procurement). If the revenue to the public budget from privatization is low, the public agent can be accused of collusion with the private agent or of "selling off the family silver" (Kolderie 1986). The corollary is that privatizations' aftermath regarding price and efficiency appears to be a sell-off from a government's valuation standpoint and rigid from a private managerial perspective.

\subsection{Immunity for Public Agents}

Many countries guarantee public agents a degree of immunity from legal prosecution as a way to insulate them from threats of media smear campaigns, courts, and legal harassment (Dal Bó et al.

\footnotetext{
${ }^{42}$ PPP and privatization differ in that the former is a transfer to the private sector of a right (which may or may not come with a physical asset) to perform the public function, while the latter usually refers to the sale of an asset which is not necessarily idiosyncratic to the public sector (e.g., liquor stores in Pennsylvania).
} 
2006). Dal Bó et al. develop a model in which the public agent cares about money, punishment, and the political cost of getting involved in a corrupt deal, e.g., the result of a detection probability (2006:45). They show (2006:49) that, by limiting the potential for pressure from interested groups, immunity may indirectly lead to an increase in the quality of public officials, and hence better public policies. Congruently, from a TPO theory perspective, immunity lowers the likelihood of successful TPO challenges $\sigma \tau$ because the public agent will not have to prove probity and, consequently, provides flexibility that leads to an increase in efficiency of public agents.

\section{An Extension: Governmental Opportunism}

In this paper, our goal was to highlight third-party opportunism implications for public contracting. However, the model can also serve to analyze the impact of governmental opportunism $(G)$ as a hazard to public contracts (Moszoro 2011).

Let $I$ be sunk investments and $A$ be the rents of the public agent from expropriation (whereas $A=I$ represents total expropriation and $A<I$ represents partial expropriation) and $\psi$ the likelihood of governmental opportunism of appropriating $A$. Expected costs of governmental opportunism equals $\mathrm{E}(G)=A \psi(R)$, where $\psi$ is assumed to decrease in contract specificity and rigidity $(\delta \psi / \delta R<0)$.

In the presence of governmental opportunism, the private contractor will respond by seeking further specificity and rigidity $R$ and charging an additional $A \psi(R)$ to her private contracting costs $K_{p r}$. For any $\psi>0$, the higher sunk investments $I$, the higher possible expropriation rents $A$ and expected costs of governmental opportunism $\mathrm{E}(G)$ (Troesken 1996), specificity and rigidity of the contract $R^{\prime}>R^{*}$, and final price $P^{\prime}>P^{\min }$ charged to the public sector (see Figure 2). A corollary of the interrelation of third-party and governmental opportunism is that higher price $P^{\prime}$ due to governmental opportunism makes the contract more vulnerable to third-party challenges, or not feasible, if the $P^{\prime}$ is above the maximum price $P^{b u d}$ that the public agent is willing or is able to pay. 


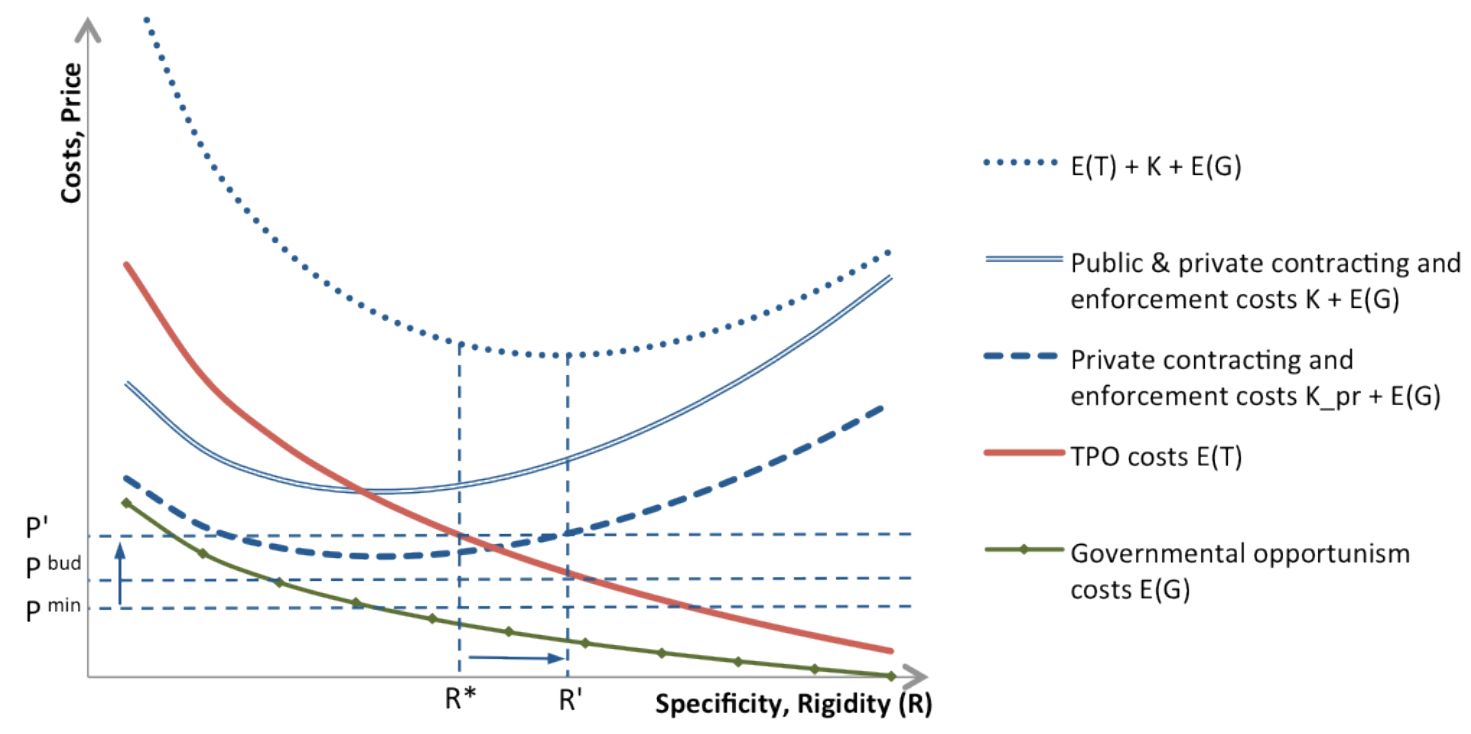

The contractor's taking out insurance against adverse political events (e.g., governmental expropriation, confiscation of assets, or repudiation of contracts) mitigates the expected costs of governmental opportunism, but shifts up the cost of contracting $K$ by the insurance premium. In a competitive insurance market, the political risk insurance premium equals the insurer's expected expropriation rents $\mathrm{E}_{\mathrm{S}}(G)$, while the contractor's willingness to pay for political risk insurance equals her expected expropriation rents $\mathrm{E}(G)$. Political risk insurance will be beneficial for the public agent only if the political risk insurance premium, compounded now in the contract price, amounts to no more than the differential between contract prices with and without political risk insurance, i.e., $\mathrm{E}_{\mathrm{S}}(G)$ $\leq P^{\prime}-P^{\min }$, this differential being due to further rigidity and the contractor's expected cost of governmental opportunism at $R^{\prime}$. Political risk insurance will be cost-efficient for the contractor if the political risk insurance premium is lower or equal to her expected cost due to governmental opportunism, i.e., $\mathrm{E}_{\mathrm{S}}(G) \leq \mathrm{E}(G)$.

If political risk insurance premiums are too low, contractors that face opportunistic-type governments will take out insurance, increasing the average claims. Contractors may also lower rigidity below the optimal level without political risk insurance due to moral hazard, sparking more governmental opportunism and further increasing the average claims. Advancing this result, the insurer will increase 
political risk premiums. If political risk insurance premiums are too high, it will not be cost-efficient for contractors of non-opportunistic-type governments to take out political risk insurance. In equilibrium without informational asymmetry on the government type, contractors will be indifferent about taking out political risk insurance. In the presence of informational asymmetry about the likelihood of governmental opportunism $\psi$, an adverse selection screening game-largely described in the literature on insurance markets-will take place, which explains high political risk insurance premiums, the existence of tiny private markets for political risk insurance, and the indispensable involvement of multilateral agencies (MLAs). ${ }^{43}$

\section{Concluding Remarks}

TPO theory combines political hazards and transaction costs to explain apparent inefficiencies in public contracts. A paramount conclusion of our analysis is that public contracts cannot be directly compared to private contracts. Instead, they can only be compared to analogous public contracts, and should pass Williamson's (1999) "remediableness criterion"44 to attest to their efficiency.

That public contracting is more expensive and rigid than private contracting, however, does not mean that transferring those activities to the public sector would reduce political risks and hence make them more efficient. Not only, as Williamson (1999:320) discussed, do certain transactions have special needs for probity and require the security of the state, ${ }^{45}$ but the privatization of public functions itself involves TPO hazards, making them less preferable for public agents than public contracting itself.

\footnotetext{
${ }^{43}$ See, for example, the Multilateral Investment Guarantee Agency (MIGA), a member of the World Bank Group (http://www.miga.org/; accessed July 15, 2011), or the Overseas Private Investment Corporation (OPIC), a U.S. Government's development finance institution (http://www.opic.gov/insurance; accessed July 15, 2011). 44 "The "remediableness criterion" holds that "an extant mode of organization for which no superior feasible alternative can be described and implemented with expected net gains is presumed to be efficient" (Williamson 1999:316; emphasis is original).

${ }^{45}$ See, also, Prendergast (2003:930-933) who claims that public procurement is used for "hard" agency problems where consumers cannot be trusted and "when bureaucracies work poorly, consumer choice works worse".
} 
In this paper we have analyzed public procurement in a variety of environments to show that much of its outer features can be understood as political adaptations to the fundamental hazard of third party opportunism prevalent in public contracting. 


\section{References}

Bajari, Patrick, and Gregory Lewis. 2010. Procurement Contracting with Time Incentives: Theory and Evidence. Mimeo. Berkeley.

Bajari, Patrick, and Gregory Lewis. 2001. Incentives versus Transaction Costs: A Theory of Procurement Contracts. RAND Journal of Economics 32 (3):387-407.

Baldwin, J. Norman. 1990. Perceptions of Public versus Private Sector Personnel and Informal Red Tape: Their Impact on Motivation. The American Review of Public Administration 20 (1):728.

Bambaci, Juliana, Pablo T. Spiller, and Mariano Tommasi. 2007. The Bureaucracy. In The Institutional Foundations of Public Policy in Argentina, edited by P. T. Spiller and M. Tommasi. New York: Cambridge University Press.

Becker, Gary. 1983. A theory of competition among pressure groups for political influence. Quarterly Journal of Economics 98:371-400.

Boyne, George A. 2002. Public and Private Management: What's the Difference? Journal of Management Studies 39 (1):97-122.

Bozeman, Barry. 1993. A Theory of Government 'Red Tape'. Journal of Public Administration Research and Theory 3 (3):273-303.

Brench, Andreas, Thorsten Beckers, Maria Heinrich, and Christian von Hirschhausen. 2005. PublicPrivate Partnerships in New EU Member Countries of Central and Eastern Europe. European Investment Bank 10 (2).

Buchanan, James. 1965. An economic theory of clubs. Econometrica 33:1-14.

Buchanan, James. 1975. A contracting paradigm of applying economic theory. American Economic Review 65 (May):225-230. 
Buchanan, James, Robert D. Tollison, and Gordon Tullock, eds. 1980. Toward a Theory of the RentSeeking Society. College Station: Texas A\&M Press.

Carlson, Ingrid, and J. Mark Payne. 2003. Estudio comparativo de estadísticas de empleo público en 26 países de América Latina y el Caribe. In Red de gestión y transparencia de la política pública. Servicio civil: temas para el diálogo, edited by K. Echebarría. Washington, DC: Inter-American Development Bank.

Coase, Ronald H. 1937. The Nature of the Firm. Economica 4 (16):386-405.

Coviello, Decio, and Stefano Gagliarducci. 2010. Tenure in Office and Public Procurement. SSRN eLibrary.

Dal Bó, Ernesto, Pedro Dal Bó, and Rafael Di Tella. 2006. Plata o Pomo? Bribe and Punishment in a Theory of Political Influence. American Political Science Review 100 (1):41-53.

de Figueiredo, Rui J. P., Jr., Pablo T. Spiller, and Santiago Urbiztondo. 1999. An Informational Perspective on Administrative Procedures. Journal of Law, Economics, and Organization 15 (1):283-305.

Department of Defense. 2011. Source Selection Procedures. Available at: http://www.acq.osd.mil/dpap/policy/policyvault/USA007183-10-DPAP.pdf (accessed May $19,2011)$.

Department of Treasury and Finance of Victoria. 2001. Partnerships Victoria Guidance Material: Public Sector Comparator-Technical Note. Melbourne.

Economic Planning Advisory Commission. 1995. Final Report of the Private Infrastructure Task Force. Canberra: Australian Government Publishing Service. 
Engel, Eduardo, Ronald Fischer, and Alexander Galetovic. 2006. Renegotiation Without Holdup: Anticipating Spending in Infrastructure Concessions. Cowles Foundation Discussion Paper 1567.

Fehr, Ernst, Oliver Hart, and Christian Zehnder. 2011. Contracts as Reference Points-Experimental Evidence. American Economic Review 101 (2):493-525.

Ferejohn, John. 1990. Congressional Influence on Bureaucracy. Journal of Law, Economics, and Organization 6:1-20.

Fogel, Ramón. 1993. La estructura social paraguaya y su incidencia en la transición a la democracia. In Paraguay en Transición, edited by D. A. Brun. Caracas: Editorial Nueva Sociedad.

Forrer, John, James Edwin Kee, Kathryn E. Newcomer, and Eric Boyer. 2010. Public-Private Partnerships and the Public Accountability Question. Public Administration Review May/June:475-484.

GAO. 2001. Contract Management. Benefits of Simplified Acquisition Test Procedures Not Clearly Demonstrated. Washington, DC: United States General Accounting Office (GAO). Available at: http://www.gao.gov/new.items/d01517.pdf (accessed July 11, 2011).

GAO. 2003. Equal Employment Opportunity. SSA Region X's Changes to Its EEO Process Illustrate Need for Agencywide Procedures. Washington, DC: United States Government Accountability Office (GAO). Available at: http://www.gao.gov/new.items/d03604.pdf (accessed July 18, 2011).

GAO. 2008. Defense Acquisition. Assessments of Selected Weapon Programs. Washington, DC: United States General Accounting Office (GAO). Available at: http://www.gao.gov/new.items/d08467sp.pdf (accessed July 11, 2011). 
Gely, Rafael, and Pablo T. Spiller. 1990. A Rational Choice Theory of Supreme Court Statutory Decisions with Applications to the State Farm and Grove City Cases. Journal of Law, Economics, and Organization 6 (2):263-300.

Goldsmith, Stephen, and William D. Eggers. 2004. Governing by Network: The New Shape of the Public Sector. Washington, DC: Brookings Institution Press.

Guasch, J. Luis, Jean-Jacques Laffont, and Stéphane Straub. 2007. Concessions of Infrastructure in Latin America: Government-led Renegotiations. Journal of Applied Econometrics 22 (7):1267-1294.

Hammami, M., J.-F. Ruhashyankiko, and E.B. Yehoue. 2006. Determinants of Public-Private Partnerships in Infrastructure. IMF Working Paper No. 66/99.

Harris, A.C. 1996. Financing infrastructure: private profits from public losses. In Public/Private infrastructure financing: Still feasible? Sydney: Audit Office of NSW, Public Accounts Committee, Parliament of NSW.

Hart, Oliver, and John Moore. 2008. Contracts as Reference Points. Quarterly Journal of Economics $123(1): 1-48$.

Horn, Murray 1995. The Political Economy of Public Administration: Institutional Choice in the Public Sector, Political Economy of Institutions and Decisions. Cambridge, UK: Cambridge University Press.

House of Representatives Standing Committee on Communications Transport and Microeconomic Reform. 1997. Planning not Patching: An Inquiry Into Federal Road Funding. Canberra: Australian Government Publishing Service.

Iacoviello, Mercedes, and Mariano Tommasi. 2002. Diagnóstico institucional de sistemas de servicio civil: caso Argentina. In Diálogo Regional de Políticas. Buenos Aires. 
Industry Commission. 1996. Competitive Tendering and Contracting by Public Sector Agencies. Canberra: Australian Government Publishing Service.

Iossa, Elisabetta, and David Martimort. 2008. The Simple Micro-Economics of Public-Private Partnerships. CEIS Tor Vergata Research Paper Series 6 (12).

Kolderie, Ted. 1986. The Two Different Concepts of Privatization. Public Administration Review 46 (4):285-291.

Kurland, Nancy B., and Terri D. Egan. 1999. Public v. Private Perceptions of Formalization, Outcomes, and Justice. Journal of Public Administration Research and Theory 9 (3):437-458.

Laffont, Jean-Jacques, and Jean Tirole. 1991. The Politics of Government Decision-Making: A Theory of Regulatory Capture. Quarterly Journal of Economics 106 (4):1089-1127.

Laffont, Jean-Jacques, and Jean Tirole. 1993. A Theory of Incentives in Procurement and Regulation. Cambridge, MA: MIT Press.

Lan, Zhiyong, and Hal G. Rainey. 1992. Goals, Rules, and Effectiveness in Public, Private, and Hybrid Organizations: More Evidence on Frequent Assertions About Differences. Journal of Public Administration Research and Theory 2 (1):5-28.

Lobina, Emanuele, and David Hall. 2003. Problems with Private Water Concessions: A Review of the Experiences in Latin America and Other Regions. In Water Pricing and Public-Private Partnership in the Americas: Inter-American Development Bank.

Loeb, Martin P., and Krishnamurthy Surysekar. 1994. On the optimality of cost-based contracts in sole source procurement. Management Accounting Research 5 (1):31--44.

Macaulay, Stewart. 1963. Non-Contractual Relations in Business: A Preliminary Study. American Sociological Review 28 (1):55-67. 
Marshall, Robert C., Michael J. Meurer, and Jean-François Richard. 1994a. Curbing Agency Problems in the Procurement Process by Protest Oversight. RAND Journal of Economics 25:297-318.

Marshall, Robert C., Michael J. Meurer, and Jean-François Richard. 1994b. Litigation Settlement and Collusion. Quarterly Journal of Economics 109 (1):211-239.

Maser, Steven M., Vladimir Subbotin, and Fred Thompson. 2010. The Bid-Protest Mechanism: Effectiveness and Fairness in Defense Acquisitions? SSRN eLibrary.

McCubbins, Matthew D., Roger G. Noll, and Barry R. Weingast. 1987. Administrative Procedures as Instruments of Political Control. Journal of Law, Economics, and Organization 3 (2):243277.

McCubbins, Matthew D., Roger G. Noll, and Barry R. Weingast. 1989. Structure and Process, Politics and Policy: Administrative Arrangements and the Political Control of Agencies. Virginia Law Review 75:431-482.

McCubbins, Matthew D., and Thomas Schwartz. 1984. Congressional Oversight Overlooked: Police Patrols versus Fire Alarms. American Journal of Political Science 28 (1):165-179.

Molinas, José, Anibal Pérez-Liñán, Sebastian M. Saiegh, and Marcela Montero. 2006. Political Institutions, Policymaking Processes and Policy Outcomes in Paraguay, 1954-2003. IDB Working Paper 201.

Moszoro, Marian. 2011. Opportunism in Public-Private Project Financing. IESE Business School Working Paper No. 887. SSRN eLibrary.

Moszoro, Marian, and Magdalena Krzyzanowska. 2008. Striving for the Quality of Public Services Through Public-Private Partnerships. The Case of 7 Projects in the City of Warsaw. Paper read at 4th International Conference: An Enterprise Odyssey: Tourism-Governance and Entrepreneurship, at Cavtat (Croatia). 
North, Douglass C., John Joseph Wallis, and Barry R. Weingast. 2006. A Conceptual Framework for Understanding Recorded Human History. NBER Working Paper 12795.

Olson, Mancur. 1965. The Logic of Collective Action: Public Goods and the Theory of Groups. Cambridge, MA: Harvard University Press.

Peltzman, Sam. 1976. Toward a more general theory of regulation. Journal of Law and Economics 19:211-240.

Pfiffner, James P. 1987. Political Appointees and Career Executives: The Democracy-Bureaucracy Nexus in the Third Century. Public Administration Review 47 (1):57-65.

Prendergast, Canice. 2003. The Limits of Bureaucratic Efficiency. Journal of Political Economy 111 (5):929-958.

Quiggin, John. 1996. Private sector involvement in infrastructure projects. Australian Economic Review (1st quarter):51-64.

Riker, William H. 1963. The Theory of Political Coalitions. New Haven: Yale University Press.

Spiller, Pablo T. 2008. An Institutional Theory of Public Contracts: Regulatory Implications. NBER Working Paper 14152.

Spiller, Pablo T., and William D. Savedoff. 2000. Oportunismo gubernamental y suministro de agua. In Agua perdida: compromisos institucionales para el suministro de servicios públicos sanitarios, edited by P. T. Spiller and W. D. Savedoff. Washington, D.C.: Banco Interamericano de Desarrollo.

Spiller, Pablo T., and Santiago Urbiztondo. 1994. Political appointees vs. career civil servants: A multiple principals theory of political bureaucracies. European Journal of Political Economy $10(3): 465-497$. 
Stigler, George J. 1971. The Theory of Economic Regulation. The Bell Journal of Economics and Management Science 2 (1):3-21.

Troesken, Werner. 1996. Why Regulate Utilities? The New Institutional Economics and the Chicago Gas Industry, 1849-1924. Ann Arbor: University of Michigan Press.

Wang, Chong, and Joseph San Miguel. 2011. Unintended Consequences of Advocating Use of FixedPrice Contracts in Defense Acquisition Practice. Paper read at the Eighth Annual Acquisition Research Symposium: Creating Synergy for Informed Change, May 11-12, 2011, at Monterey, CA.

Weingast, Barry R., and Mark J. Moran. 1983. Bureaucratic Discretion or Congressional Control? Regulatory Policymaking by the Federal Trade Commission. Journal of Political Economy 91 (5):765-800.

Williamson, Oliver E. 1975. Markets and Hierarchies: Analysis of Antitrust and Implications. New York: Free Press.

Williamson, Oliver E. 1979. Transaction-cost economics: the governance of contractual relations. Journal of Law and Economics 22 (2):233-261.

Williamson, Oliver E. 1985. The Economic Institutions of Capitalism. Firms, Markets, Relational Contracting. New York: The Free Press, Macmillan, Inc.

Williamson, Oliver E. 1999. Public and Private Bureaucracies: A Transaction Cost Economics Perspectives. Journal of Law Economics and Organization 15 (1):306-342.

Williamson, Oliver E. 2005. The Economics of Governance. American Economic Review 95 (2):118. 